Volume 13

Issue 1 Revisiting the Life and Work of Raphaël

Lemkin

Article 6

4-2019

\title{
Prosecuting Lemkin's Concept of Genocide: Successes and Controversies
}

Jonathan Hobson

university of gloucestershire

Follow this and additional works at: https://digitalcommons.usf.edu/gsp

\section{Recommended Citation}

Hobson, Jonathan (2019) "Prosecuting Lemkin's Concept of Genocide: Successes and Controversies," Genocide Studies and Prevention: An International Journal: Vol. 13: Iss. 1: 19-32.

DOI:

https://doi.org/10.5038/1911-9933.13.1.1640

Available at: https://digitalcommons.usf.edu/gsp/vol13/iss1/6

This Articles is brought to you for free and open access by the Open Access Journals at Digital Commons @ University of South Florida. It has been accepted for inclusion in Genocide Studies and Prevention: An International Journal by an authorized editor of Digital Commons @ University of South Florida. For more information, please contact digitalcommons@usf.edu. 


\title{
Prosecuting Lemkin's Concept of Genocide: Successes and Controversies
}

\author{
Jonathan Hobson \\ University of Gloucestershire \\ Cheltenham, England
}

\begin{abstract}
Introduction
As a term, genocide is a relatively recent concept devised by the lawyer Raphaël Lemkin in 1944 as a response to the organized, mechanized, and institutionalized killings that were an integral part of the Nazi regime during the Second World War. For Lemkin, Genocide was "an old practice in its modern development." ${ }^{1}$ It was not that the killings were necessarily greater in number than previous events of mass murder, or that the cultural imperialism they reflected was a new phenomenon in Europe. Rather, that the systems, structures, and technologies of modernity enabled the Nazis to undertake a process of isolation, denigration, and destruction in a more organized and orchestrated way that had happened previously. The destruction, not limited to but particularly targeted at the Jewish population of occupied Europe saw systematic abuse, disempowerment, cultural destruction and the murder of millions, many in purpose-built death camps. For Lemkin, this industrialization of the processes of discrimination and killing required a new language:
\end{abstract}

New conceptions require new terms. By genocide we mean the destruction of a nation or ethnic group ... a coordinated plan of different actions aimed at the destruction of essential foundations of life of national groups, with the aim of the destruction of the group themselves. ${ }^{2}$

Genocide is more than mass murder and cultural and economic domination: it is the biological, cultural, and social disintegration of a targeted group. In his work detailing the new terminology of genocide, Lemkin ${ }^{3}$ describes the "techniques of genocide" in different spheres of human existence, and particularly in relation to the conditions of life brought to bear on Jews in Nazi Germany. For Lemkin, the Nazi genocide was a planned and deliberate attempt to undermine and then destroy the Jewish population in all aspects of life: political, social, cultural, economic, biological, physical, religious, and moral. It was, as he described it, "an elaborate, almost scientific system, developed to an extent never before achieved by any nation." ${ }^{4}$

Subsequently codified by the United Nations in 1951, Genocide has become the focus of several international courts including the International Criminal Tribunal for the former Yugoslavia (ICTY) in 1993, the International criminal tribunal for Rwanda (ICTR) in 1994, and the International Criminal Court (ICC) founded in 1998. These legal bodies represent a voice for the international community and a statement of intent when it comes to collective action on the continued perpetration of a crime that should "shock the conscience of humanity." ${ }^{5}$

The international bodies responsible for prosecuting genocide are not without their critics. For instance, the professor of international Law, William Schabas, ${ }^{6}$ identifies issues with the definitions of genocide used in international legislation. Barria and Roper $^{7}$ are skeptical on the impact of the early international tribunals in both prosecuting individuals and in contributing to more lasting peace in the regions. There are also critiques on the role that the International Criminal Court in

\footnotetext{
${ }^{1}$ Raphaël Lemkin, Axis Rule in Occupied Europe: Laws of Occupation, Analysis of Government, Proposal for Redress

(Washington, DC: Carnegie Endowment for International Peace, 1944), 79.

2 Ibid., 79.

${ }^{3}$ Ibid., 83.

${ }^{4}$ Ibid., 84 .

${ }^{5}$ United Nations, Rome Statute of the International Criminal Court. July 17, 1998 and corrected by process-verbaux of November 10, 1998, July 12, 1999, November 30, 1999, May 8, 2000, January 17, 2001 and January 16, 2002 (UN Doc. A/ CONF.183/9).

${ }^{6}$ William Schabas, Convention for the Prevention and Punishment of the Crime of Genocide, (United Nations Audiovisual Library of International Law, 2008), accessed June 10, 2018, http://legal.un.org/avl/pdf/ha/cppcg/cppcg e.pdf.

${ }^{7}$ Lilian Barria and Steven Roper, "How Effective are International Criminal Tribunals? An Analysis of the ICTY and the ICTR," International Journal of Human Rights 9, no. 3 (2005), 349-368.
} 
sovereign states, particularly in Africa, where Abdul Tejan-Cole ${ }^{8}$ argues that the work of the ICC in Africa has opened it up to criticisms of neo-colonialism on that continent. This is a position taken by the African Union, who have persistently criticized the ICCs involvement in African Affairs and have gone as far as to recommend that its member states do not comply with ICC arrest warrants. Nevertheless, many argue that the international tribunals and the ICC have had a significant and positive impact. For instance, Hyeran and Simmons, ${ }^{9}$ Bassiouni and Hansen, ${ }^{10}$ and Hillebrecht ${ }^{11}$ all see the prosecutions and the wider work of the international tribunals and courts as an opportunity to establish international norms around prosecuting genocide, changing habits and deterring, or at least dampening the extent of future genocidal events. This paper examines the impact of international efforts towards prosecuting genocide, considering the legislative journey the crime has been through, the prosecutions for genocide to date, and the difficulties around the politicization of the international courts.

\section{Structure and Data}

The paper is in three parts. The first part examines the history of genocide legislation, in particular the international legal frameworks established since Lemkin first devised the term in 1944. The second part details the extent of genocide prosecutions to date, employing material from various international criminal tribunals, the ICC, national courts, and, where necessary, media accounts contemporary with the events. The final part illustrates the politics involved in genocide prosecutions through a case study of ICC involvement in Africa and the failed extradition of Sudanese president Omar Al Bashir. The case study uses a range of secondary sources, including documents from the ICC, the African Union, National Governments, and other contemporary accounts.

\section{Legislating Genocide: From Lemkin to the ICC}

The first significant appearance of the term genocide after Lemkin's inception of the term in 1944 was during the trials in Nuremburg and Tokyo after the Second World War. These trials were based on two important pieces of legislation: the "Charter of the International Military Tribunal", which was presented in June 1945 and formed the basis for the trials of Nazi party members at Nuremburg, ${ }^{12}$ and in September 1945, the "International Military Tribunal for the Far East Charter," which was the basis for trials of Japanese prisoners in Tokyo. The subsequent prosecutions were in part the realization of the "Moscow Declaration" (and subsequent "London agreement," both more commonly associated with the establishment of the United Nations) signed on October 30, 1943, on behalf of the Governments of the United Kingdom, United States, Soviet Union, and Nationalist China. These declarations promised a "rapid and orderly transition from war to peace and of establishing and maintaining international peace and security." ${ }^{13}$

The legislation adopted as part of the trials at Nuremburg and Tokyo were important for several reasons. Common to both trials was a list of three crimes: crimes against peace, war crimes, and crimes against humanity,$^{14}$ one of the first occasions on which such serious acts of widespread violence, aggression, and destruction were codified at an international level. Although the term genocide was not listed as a crime at either trial, it was referred to during the hearings. More broadly, both trials contributed to the concept of achievable international justice and standards

\footnotetext{
${ }^{8}$ Abdul Tejan-Cole, "Is the ICC's exclusively African case docket a legitimate and appropriate intervention or an unfair targeting of Africans?," in Contemporary Issues Facing the International Criminal Court, ed. Richard H. Steinberg (Leiden: Brill, 2016), 366-379.

9 Jo Hyeran and Beth Simmons, “Can the International Criminal Court Deter Atrocity?" International Organization 70, no. 3 (2016), 443-475.

${ }^{10}$ M. Cherif Bassiouni and Douglass Hansen, "The Inevitable Practice of the Office of the Prosecutor," in Contemporary Issues Facing the International Criminal Court, ed. Richard H. Steinberg (Leiden: Brill, 2016), 309-325.

${ }^{11}$ Courtney Hillebrecht, "The Deterrent Effects of the International Criminal Court: Evidence from Libya," International Interactions 42, no. 4 (2016), 616-643.

${ }^{12}$ United Nations, The Charter and Judgment of the Nürnberg Tribunal - History and Analysis, Memorandum submitted by the Secretary-General, Formulation of the Nürnberg Principles, 1949. (UN Doc. A/CN.4/5).

${ }^{13}$ United Nations, The Yearbook of the United Nations 1946-17 (New York: United Nations Publications, 1947), 3.

${ }^{14}$ United Nations, Charter.
} 
around serious crimes that constituted violations of individual and collective liberties. The Charter and judgment of the Nuremberg Tribunal included a series of "Principles of International Law" that were subsequently adopted by the International Law Commission of the United Nations, in 1950. ${ }^{15}$ This codified the three crimes considered at Nuremburg and Tokyo into international statute and set out the criteria for holding to account those responsible. It also sought to determine several questions of international criminal jurisdiction, including for the crime of "genocide," specifically:

...the desirability and possibility of establishing an international judicial organ for the trial of persons, charged with genocide or other crimes over which jurisdiction will be conferred upon that organ by international convention. ${ }^{16}$

The inclusion of the term genocide in the text from the International Law Commission was a significant milestone in the recognition and management of the crime. At the same time as Nuremburg, in Tokyo the United Nations was running a parallel conference debating Lemkin's term genocide in relation to the crimes committed in the Far East during the Second World War. This conference culminated in the "Convention for the Prevention and Punishment of the Crime of Genocide," which was adopted by the United Nations General Assembly on December 9, 1948, and enacted in law 12 January $1951 .{ }^{17}$ This legislation, based on the work of Lemkin, defined Genocide in legal terms as:

... Any of the following acts committed with intent to destroy, in whole or in part, a national, ethnical, racial or religious group, as such:

(a) Killing members of the group;

(b) Causing serious bodily or mental harm to members of the group;

(e) Deliberately inflicting on the group conditions of life calculated to bring about its physical destruction in whole or in part;

(f) Imposing measures intended to prevent births within the group;

(e) Forcibly transferring children of the group to another group. ${ }^{18}$

The Convention for the Prevention and Punishment of Genocide was the first human rights treaty adopted by the United Nations General assembly. It uses much of the same language and precedents set out in the "Principles of International Law" recognized in the Charter of the Nuremberg Tribunal, particularly around the culpability of perpetrators and the responsibility of the international community in prosecuting the crime.

Although there is some evidence to show that the term genocide was used in at least one successful prosecution before 1990, in Equatorial Guinea (as detailed in next section of this paper), it is generally accepted that the legislation governing genocide was not acted upon, certainly at an international level, until the early 1990s when the United Nations used the Genocide Convention to establish the International Criminal Tribunals for the former Yugoslavia and for Rwanda (ICTY and ICTR). There are several reasons for this period of inactivity, chief among them was the international paralysis caused by the Cold War, lack of consensus across the UN, and, as Schabas ${ }^{19}$ points out, a practical difficulty in that "the Genocide Convention does not establish a monitoring mechanism." Nevertheless, in 1993 the United Nations established the International

\footnotetext{
${ }^{15}$ United Nations, Yearbook of the International Law Commission 1950, Vol. 2 (New York: United Nations Publication, 1957), 374-378. 
Criminal Tribunal for the Former Yugoslavia ${ }^{20}$ with a mandate to prosecute those responsible for serious violations of international humanitarian law during the break-up of the former Yugoslavia, including grave breaches of the Geneva Conventions, violations of the laws or customs of war, crimes against humanity, and genocide. Then, in 1994 following the brutal and violent civil war, the United Nations established the International Criminal Tribunal for Rwanda, charged with prosecuting a similar range of crimes (UNHCR 2016). The ICTR ended its work on December 25, 2015, whilst that of the ICTY continues.

Although the ICTY and ICTR were the first international use of the genocide conventions, Schabas ${ }^{21}$ is somewhat circumspect about the application of the legislation in these courts, describing "a restrictive approach to interpretation of the definition of genocide, which was made evident in the two ad hoc tribunals for the former Yugoslavia and Rwanda." This critique is supported by Barria and Roper, who identify a range of difficulties with ICTY and ICTR, for example that some of the "problems of the tribunals are due to the nature of international humanitarian law and their broad mandate." ${ }^{22}$ This is not to say that these tribunals were without merit; it is important to note that they did signify a willingness on the part of the international community to focus on some of the most extreme cases of state-sanctioned and organized violence. Nevertheless, it was some of the perceived failings of the ICTY and ICTR that were part of the "primary justifications for the creation of an International Criminal Court" 23 as a more permanent body to oversee the prosecution of the crime of genocide.

Enacted on July 1, 2002, the Rome Statue established the International Criminal Court (ICC) with jurisdiction over Genocide, Crimes against Humanity, and War Crimes, "the most serious crimes of concern to the international community." 24 The ICC is funded on a similar model to the UN, where contributions are based roughly on member states' GDP. 18 judges are elected by the Assembly of States Parties for nine years, currently: Argentina, Dominican Republic, Trinidad and Tobago, Kenya, Botswana, Democratic Republic of Congo, Nigeria, Belgium, Italy, United Kingdom, Czech Republic, France, Poland, Germany, Hungary, Japan, and Republic of Korea, the Philippines. ${ }^{25}$ Investigations are initiated based on a referral from the UN Security Council, from a petition by a State, or through an ICC investigation initiated by the Office of the Prosecutor. ${ }^{26}$ The next section of this paper details the successes of genocide prosecution worldwide, providing the sum of prosecutions to date and the organizations or bodies responsible for those prosecutions.

\section{Prosecuting Genocide: Contested Success}

As of January 1, 2018, there have been 150 identifiable prosecutions for genocide, although in 7 cases those found guilty were subsequently acquitted. These are prosecutions that have listed genocide as at least one of the offenses for which an individual has been found guilty. In many cases there are other offenses alongside genocide convictions, most commonly Crimes against Humanity or grave breaches of the international laws governing war (i.e. serious breaches of the Geneva Convention), however these are not detailed in the following lists. The convictions for genocide are organized into three groups: those pursuant to the war in the Rwanda (Table 1); those pursuant to the war in the former Yugoslavia (Table 2); cases across the rest of the world, including those from the ICC (Table 3). In the first two groups many of the convictions came through the work of the ICTY and ICTY. Despite the criticisms of these courts, they both have successfully prosecuted individuals for

\footnotetext{
${ }^{20}$ United Nations, Updated Statute of the International Criminal Tribunal for the Former Yugoslavia, September 2009, compilation based on original United Nations resolutions, accessed October 6, 2018, http://www.icty.org/x/file/Legal Library/Statute/statute sept09 en.pdf, 278.

${ }^{21}$ Schabas, Convention, 4.

${ }^{22}$ Barria and Roper, Effective, 364.

${ }^{23}$ Ibid., 349.

${ }^{24}$ United Nations, Rome Statute, 2.

${ }^{25}$ International Criminal Court, “Current Judges," Judicial Divisions, accessed October 6, 2018, https://www.icc-cpi.int/ about/judicial-divisions/biographies.

${ }^{26}$ International Criminal Court, “Understanding the International Criminal Court," Public Information and Documentation Section, accessed October 6, 2018, https://www.icc-cpi.int/iccdocs/pids/publications/uicceng.pdf, 17.
} 
the crime of genocide, with the ICTR is responsible for the largest number of individual genocide trials, and for 59 convictions.

Each table lists convictions in that group by prosecuting body and in chronological order, combining convictions together where prosecuting bodies have done so. The tables identify the specific crime for which individuals were convicted, the sentence they received, and whether that sentence was reduced, commuted or overturned on appeal. Each table is followed by some discussion on issues of importance. Where sentences are listed as "Life" this reflects the term given by the specific court and may vary depending on the legislation used in each case.

Table 1. Genocide Prosecutions Pursuant to the War in Rwanda

\begin{tabular}{|c|c|c|c|}
\hline $\begin{array}{l}\text { Table Key: D } \\
\text { (i) Genoc } \\
\text { (ii) Consp } \\
\text { (iii) Direct } \\
\text { (iv) Comp }\end{array}$ & $\begin{array}{l}\text { tion of genocide conviction } \\
\text { ublic incitement to commit genocide } \\
\text { n genocide }\end{array}$ & & \\
\hline \multicolumn{4}{|c|}{ Prosecutions by the International Criminal Tribunal for Rwanda (ICTR) } \\
\hline Date & Name(s) & Conviction & Sentence \\
\hline Sept 1998 & Jean-Paul Akayesu & (i) (iii) & Life \\
\hline Sept 1998 & Jean Kambanda & (i) (ii) (iii) (iv) & Life \\
\hline Feb 1999 & Omar Serushago & (i) & 15 years \\
\hline May 1999 & Clément Kayishema ; Obed Ruzindana & (i) & Life; 25 years (respectively) \\
\hline Dec 1999 & Georges Rutaganda & (i) & Life \\
\hline Jan 2000 & Alfred Musema & (i) & Life \\
\hline June 2000 & Georges Ruggiu & (iii) & 12 years \\
\hline Feb 2003 & Elizaphan Ntakirutimana; Gérard Ntakirutimana & (i) & $\begin{array}{l}10 \text { years and } 25 \text { years } \\
\text { (respectively) }\end{array}$ \\
\hline May 2003 & Eliézer Niyitegeka & (i) (ii) (iii) & Life \\
\hline May 2003 & Laurent Semanza & (iv) & 35 years \\
\hline Dec 2003 & $\begin{array}{l}\text { Jean-Bosco Barayagwiza ; Ferdinand Nahimana; } \\
\text { Hassan Ngeze }\end{array}$ & (i) (ii) (iii) (iv) & $32 ; 30 ; 35$ years (respectively) \\
\hline Dec 2003 & Juvénal Kajelijeli & (i) (iii) & 45 years \\
\hline Jan 2004 & Jean de Dieu Kamuhanda & (i) (iii) & Life \\
\hline Feb 2004 & Samuel Imanishimw & (i) & 12 years \\
\hline June 2004 & Sylvestre Gacumbitsi & (i) & 30 years \\
\hline July 2004 & Emmanuel Ndindabahizi & (i) & Life \\
\hline April 2005 & Mikaeli Muhimana & (i) & Life \\
\hline Dec 2005 & Aloys Simba & (i) & 25 years \\
\hline Dec 2006 & Athanase Seromba & (i) & Life \\
\hline Dec 2007 & François Karera & (i) & Life \\
\hline Nov 2008 & Siméon Nchamihigo & (i) & 40 years \\
\hline Dec 2008 & $\begin{array}{l}\text { Théoneste Bagosora ; Aloys Ntabakuze ; Anatole } \\
\text { Nsengiyumva }\end{array}$ & (i) & $\begin{array}{l}35 \text { years each (Nsengiyumva } \\
\text { reduced to } 15 \text { years on appeal) }\end{array}$ \\
\hline Dec 2008 & Simon Bikindi & (iii) & 15 years \\
\hline
\end{tabular}


Table 1. continued.

\begin{tabular}{|c|c|c|c|}
\hline Dec 2008 & Protais Zigiranyirazo & (i) & Life (subsequently acquitted) \\
\hline Nov 2008 & Siméon Nchamihigo & (i) & 40 years \\
\hline Feb 2009 & Emmanuel Rukundo & (i) & 23 years \\
\hline June 2009 & Callixte Kalimanzira & (i) (iii) & 25 years \\
\hline July 2009 & Tharcisse Renzaho & (i) & Life \\
\hline Sept 2009 & Michel Bagaragaza & (iv) & 8 years \\
\hline Feb 2010 & Tharcisse Muvunyi & (iii) & 15 years \\
\hline Feb 2010 & Ephrem Setako & (i) & 25 years \\
\hline July 2010 & Yussuf Munyakazi & (i) & 25 years \\
\hline Aug 2010 & Dominique Ntawukulilyayo & (i) & 20 years \\
\hline Nov 2010 & Gaspard Kanyarukiga & (i) & 30 years \\
\hline Dec 2010 & Ildephonse Hategekimana & (i) & Life \\
\hline Mar 2011 & Jean Baptiste Gatete & (i) & 40 years \\
\hline May 2011 & Augustin Ndindiliyimana ; Augustin Bizimungu & (i) & $\begin{array}{l}11 \text { years (subsequently } \\
\text { acquitted); } 30 \text { years } \\
\text { (respectively) }\end{array}$ \\
\hline June 2011 & $\begin{array}{l}\text { Pauline Nyiramasuhuko; Arsène Shalom Ntahobali; } \\
\text { Sylvain Nsabimana; Alphonse Nteziryayo; Joseph } \\
\text { kanyabashi; Élie Ndayambaje }\end{array}$ & (i) & $\begin{array}{l}\text { Life, life, } 25,30,35, \text { life } \\
\text { (subsequently acquitted) } \\
\text { (respectively) }\end{array}$ \\
\hline Sept 2011 & Justin Mugenzl ; Prosper Mugiraneza & (ii) (iii) & $\begin{array}{l}30 \text { years each (both } \\
\text { subsequently acquitted) }\end{array}$ \\
\hline Dec 2011 & Grégoire Ndahimana & (i) & 25 years \\
\hline Feb 2012 & Édouard Karemera; Matthieu Ngirumpats & (i) (ii) (iii) & Life \\
\hline May 2012 & Callixte Nzaboniman & (i) (ii) (iii) & Life \\
\hline June 2012 & Ildéphonse Nizeyimana & (i) & 35 years \\
\hline June 2012 & Joseph Serugendo & (iii) & 6 years \\
\hline Dec 2012 & Augustin Ngirabatware & (i) (iii) & 30 years \\
\hline \multicolumn{4}{|c|}{ Other prosecutions for Genocide committed in Rwanda } \\
\hline Date & Name(s) and prosecutor & Conviction & Sentence \\
\hline \multirow[t]{2}{*}{ Feb 1997} & Froduald Karamira & (i) & Death \\
\hline & Court of First Instance of Kigali, Rwanda & & \\
\hline June 2001 & $\begin{array}{l}\text { Vincent Nteziman ; Iphonse Higaniro; Sister } \\
\text { Gertrude (a.k.a. Consolata Mukangango); Sister } \\
\text { Kisito a.k.a. Julienne Mukabutera) } \\
\text { Boutare Four trial: Assize Court, Belgium }\end{array}$ & (i) & $\begin{array}{l}12 \text { years; } 20 \text { years; } 15 \text { years; } 12 \\
\text { years (respectively) }\end{array}$ \\
\hline Nov 2006 & $\begin{array}{l}\text { Wenceslas Munyeshyaka (tried in absentia) } \\
\text { Rwandan Military Court, Kigali }\end{array}$ & (i) & Life \\
\hline Mar 2009 & $\begin{array}{l}\text { Béatrice Nirere } \\
\text { "Gagcaca" Court of Giporoso, Gasabo District, } \\
\text { Rwanda }\end{array}$ & (i) & Life \\
\hline Oct 2009 & $\begin{array}{l}\text { Désiré Munyaneza } \\
\text { Superior Court, Criminal Division, Canada }\end{array}$ & (i) & Life \\
\hline
\end{tabular}


Table 1. continued.

\begin{tabular}{llll}
\hline Dec 2009 & $\begin{array}{l}\text { Valérie Bemeriki } \\
\text { “Gagcaca” Court of Nyakabanda, Kigali, Rwanda }\end{array}$ & (i) & Life \\
\hline June 2010 & $\begin{array}{l}\text { François Bazaramba } \\
\text { District Court of Porvoo, Finland }\end{array}$ & (i) & \\
\hline Mar 2014 & Pascal Simbikangwa & & (iv) \\
& The Assize Court of Paris, France & & \\
\hline Dec 2015 & $\begin{array}{l}\text { Jean Uwinkindi - } \\
\text { Rwandan High Court }\end{array}$ & (i) \\
\hline April 2017 & Bernard Munyagishari \\
& Rwandan High Court & (i) & Life \\
\hline
\end{tabular}

As table 1 shows, as well as a considerable number of trials conducted by the ICTR, the Rwandan Government in various courts also tried those responsible for Genocide. Although table 1 reflects the largest number of cases, this is by no means the sum of all trials relating to genocide in Rwanda. Between 1997 and 2004, 10,026 cases were tried by the national courts system under a new form of "Organic Law," devised specifically to deal with the post-genocide trials. ${ }^{27}$ Organic law split cases into four categories, with the most serious, Category 1, referring directly to those "whose criminal acts or criminal participation place among planners, organizers, imitators, supervisors of the crime of genocide or crime against humanity, ${ }^{128}$ some of these are captured in the table above. Categories 2,3 , and 4 include crimes where the accused are complicit, accomplices, or perpetrators of acts of violence associated to crimes that may include genocide.

Given the difficulties of trying the substantial number of those incarcerated and awaiting trial, in 2004 the Rwandan government developed the gacaca system of localized, community trials that were a "relatively informal, traditional Rwandan method of conflict resolution that was adapted to meet the discerned needs of the post-genocide environment." ${ }^{29}$ The gacaca courts dealt predominantly with Category 2, 3 and 4 cases under Organic Law, and Nwoye ${ }^{30}$ describes the process as "a result of the domestic system's inability to deal with the huge number of back-logged genocide cases promptly." According to Human Rights Watch, of the roughly 818,000 individuals accused of crimes in the initial gacaca phase between 2004-5, 77,000 were initially placed in Organic Law Category 1 to be tried in the national court system, with the remainder of the cases sent to the gacaca courts. ${ }^{31}$ As of April 2012, approximately 1,951,388 cases had been tried in the gacaca system, with a conviction rate running around $65 \%$. The trials of political and military leaders for acts of genocide are generally well documented and included in Table 1, however there are a multitude of other crimes associated with the genocide, such as the localized support, complicity, and/or conspiracy to commit genocide that are not included in official figures but were part of national or gacaca trials. Therefore, it is very difficult to provide a firm number of the broader set of convictions related to genocide that came from these processes, but it is certain that many individuals were convicted of such crimes.

As with the war in Rwanda, the conflict in the Former Yugoslavia resulted in convictions for crimes of genocide. Table 2 shows these convictions, including those rating to the ICTY and convictions from other courts.

\footnotetext{
${ }^{27}$ Leo C. Nwoye, "Partners or Rivals in Reconciliation? The ICTR and Rwanda's Gacaca Courts," San Diego International Law Journal 16, no. 1 (2014), 184.

${ }^{28}$ Republic of Rwanda, Organic Law No. 40/2000, January 26, 2001, accessed October 6, 2018, http://jurisafrica.org/docs/ statutes/ORGANIC\%20LAW\%20N0\%2040.pdf.

${ }^{29}$ Nwoye, Partners, 125.

${ }^{30}$ Ibid., 183.

${ }^{31}$ Human Rights Watch, “Law and Reality: Progress in Judicial Reform in Rwanda," accessed October 6, 2018, https:// www.hrw.org/report/2008/07/25/law-and-reality/progress-judicial-reform-rwanda.
} 
Table 2. Genocide Prosecutions Pursuant to the War in Former Yugoslavia.

\begin{tabular}{|c|c|c|c|}
\hline \multicolumn{4}{|c|}{ Table Key: Description of genocide conviction } \\
\hline \multicolumn{4}{|c|}{ (i) Genocide } \\
\hline \multicolumn{4}{|c|}{ Conspiracy to commit genocide } \\
\hline \multicolumn{4}{|c|}{ Direct and public incitement to commit genocide } \\
\hline \multicolumn{4}{|c|}{ Complicity in genocide } \\
\hline \multicolumn{4}{|c|}{ Aiding and abetting genocide } \\
\hline \multicolumn{4}{|c|}{ Prosecutions by the International Criminal Tribunal for the former Yugoslavia (ICTY) } \\
\hline Date & Name(s) & Conviction & Sentence \\
\hline April 2004 & Radislav Krstić & (v) & 35 years \\
\hline June 2010 & Vujadin Popović & (i) (ii) & Life \\
\hline June 2010 & Ljubiša Beara & (i) & Life \\
\hline June 2010 & Drago Nikolić & (v) & 35 years \\
\hline Dec 2012 & Zdravko Tolimir & (i) (ii) & Life \\
\hline Mar 2016 & Radovan Karadžić & (i) & 40 years \\
\hline Nov 2017 & Ratko Mladić & (i) & Life \\
\hline \multicolumn{4}{|c|}{ Other Prosecution for Genocide Committed in the Former Yugoslavia } \\
\hline Date & Name and prosecutor & Conviction & Sentence \\
\hline \multirow[t]{2}{*}{ Sept 1997} & Nikola Jorgić & (i) & Life \\
\hline & German Higher Court & & \\
\hline \multirow[t]{2}{*}{ Mar 1993} & Borislav Herak & (i) & Death (subsequently revised \\
\hline & Sarajevo Military District Court & & to 20 years) \\
\hline \multirow[t]{3}{*}{ Mar 1993} & Sretko Damjanović & (i) & Death (subsequently \\
\hline & Court of Bosnia and Herzegovina, War Crimes & & acquitted) \\
\hline & Chamber & & \\
\hline \multirow[t]{2}{*}{ Nov 1999} & Maksim Sokolović & (v) & 9 years \\
\hline & German Higher Court & & \\
\hline \multirow[t]{3}{*}{ Oct 2009} & Milorad Trbić & (i) & 30 years \\
\hline & Court of Bosnia and Herzegovina, War Crimes & & \\
\hline & Chamber & & \\
\hline
\end{tabular}

Although the ICTR and ICTY are responsible for the largest number of identifiable genocide convictions, there have been convictions across the rest of the world. The first convictions for genocide are often credited to the ICTY and ICTR, however almost 20 years earlier, in 1979, there were several successful prosecutions for Genocide arising from the military coup in Equatorial Guinea. These prosecutions are often discounted over questions on the legality of the court and the legal basis used to define Genocide. The trial in Equatorial Guinea used a definition for genocide developed a few years earlier in a Spanish military court, and although the Spanish case was ultimately dismissed, the supreme military court of Equatorial Guinea used this definition as part of their prosecution of the former president and six other high-ranking officials in a set of trials after the coup. The sole international observer of the trial, Alejandro Artucio who was present on behalf of the International Commission of Jurists, cast doubt on the trial for "a series of irregularities" during the proceedings. ${ }^{32} \mathrm{He}$ argues that the charges of genocide were not legally valid, as Equatorial Guinea had not ratified the 1948 convention on the prevention and punishment of genocide. Furthermore, he argues that the charges of genocide, particularly the intent to destroy a religious, national or racial group, were not proven in the case, but rather the terms "genocide and

${ }^{32}$ Alejandro Artucio, The Trial of Macias in Equatorial Guinea: The Story of a Dictatorship (Geneva: International Commission of Jurists, 1979), 56. 
mass murder were used synonymously." 33 Nevertheless, the neglect of the Equatorial Guinea case represents an unfair erasure; it was the first time in which a legally defined concept of genocide was successfully prosecuted. During the trials in Equatorial Guinea genocide was cited as a crime, with a definition based on the prior Spanish civil and military definition. Despite the irregularities identified by the Artucio, the convictions in Equatorial Guinea have a genuine case to be regarded as the first for genocide. These convictions are included in Table 3 along with cases from elsewhere in the world.

Table 3. Genocide Prosecutions Pursuant to Cases in the Rest of the World

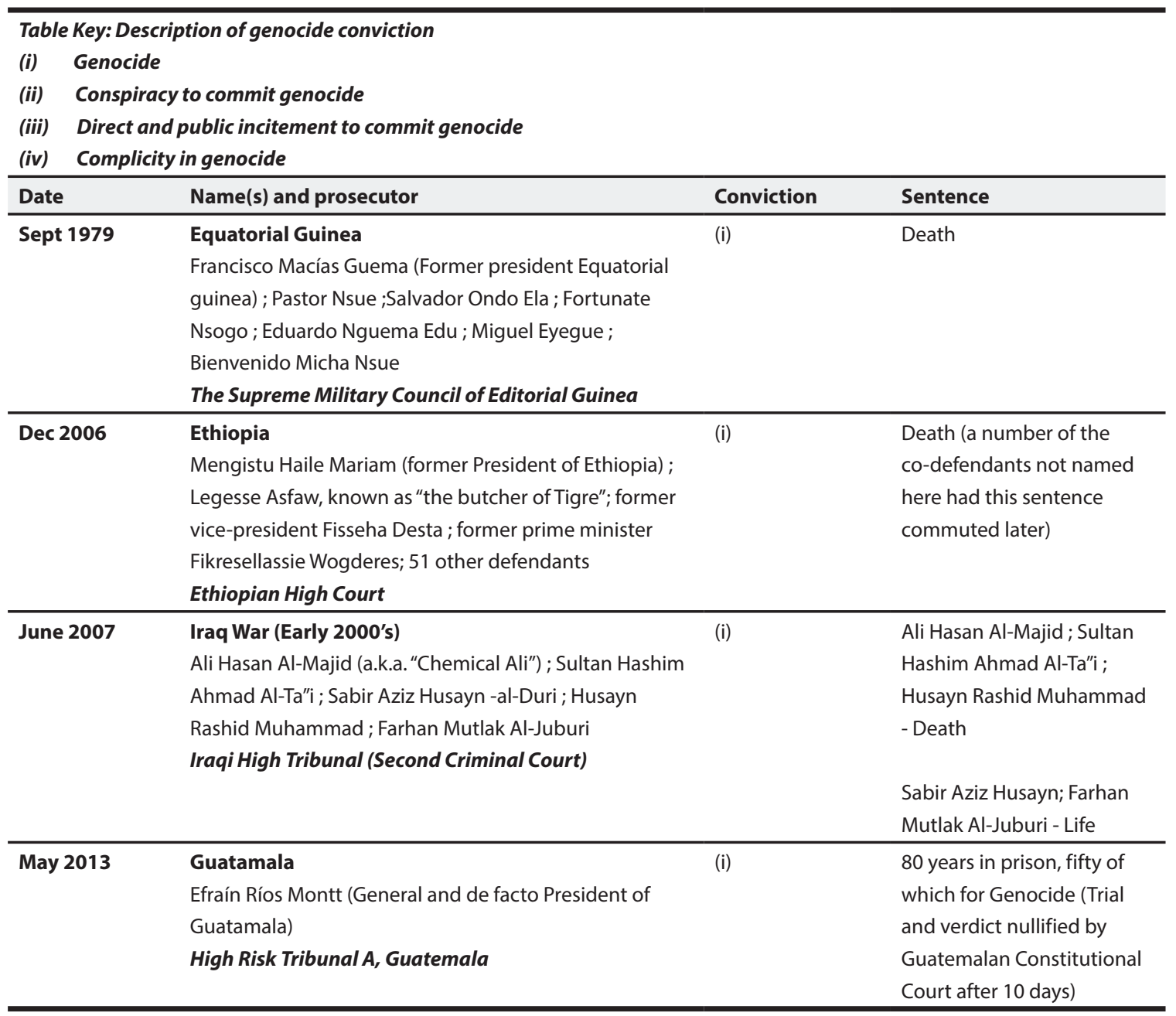

Although there have been a number of successful trials, the relatively low number of convictions outside of the Rwanda context highlight the difficulty of achieving successful prosecution in a crime as complicated as genocide, where a dolus specialis (particular intent) of group destruction must be proven. ${ }^{34}$ This is not the only difficulty in genocide prosecution; the realpolitik of criminal justice, particularly at an international level, is such that the intentional bodies investigating and trying Genocide have come under considerable scrutiny and, at times, heavy criticism. The next

\footnotetext{
${ }^{33}$ Ibid., 31

${ }^{34}$ Jonathan Hobson, “Three Theoretical Approaches to Lemkin's Definition of Genocide," Genocide Studies and Prevention 13, no. 1 (2019), 11-18.
} 
section discusses some of difficulties in achieving prosecutions, using the work of ICC in Africa and the case of Sudanese present Omar Al Bashir as an example.

\section{The Politics of Genocide Prosecution: A Case Study on the ICC in Africa}

Of the 124 countries that are parties to the Rome Statute of the ICC, 34 are African states and many of these were "deeply involved in creating the Court and all its provisions." ${ }^{35}$ Nevertheless, there has been a persistent critique of the ICCs role in Africa, much of this from a number of African States claiming that the Court "has preoccupied itself with Africa and failed to investigate equally severe conflicts elsewhere." 36 Table 4 shows the history of ICC cases, illustrating a preponderance of cases in Africa. Although genocide is listed in several of the cases, convictions to date have been restricted to crimes against humanity and war crimes.

Table 4. ICC Cases up to January 2018

\begin{tabular}{|c|c|c|c|c|c|}
\hline & Africa & Asia & Europe & North America & South America \\
\hline $\begin{array}{l}\text { Investigations not taken to } \\
\text { preliminary examination }\end{array}$ & 0 & 1 & 0 & 1 & 1 \\
\hline $\begin{array}{l}\text { Investigations taken to preliminary } \\
\text { examination }\end{array}$ & 4 & 2 & 3 & 0 & 1 \\
\hline $\begin{array}{l}\text { Situations currently under } \\
\text { investigation }\end{array}$ & 10 & 0 & 1 & 0 & 0 \\
\hline In Trial & 4 & 0 & 0 & 0 & 0 \\
\hline Acquitted or charges not confirmed & 5 & 0 & 0 & 0 & 0 \\
\hline Convicted & 3 & 0 & 0 & 0 & 0 \\
\hline Convicted but in Appeal & 2 & 0 & 0 & 0 & 0 \\
\hline
\end{tabular}

Source: ICC, $2018 b$

There is a spectrum of positions on the ICCs role in Africa, ranging from accusations of western neo-colonialism to the application of legislation governing intervention. In the first instance, Abdul Tejan-Cole ${ }^{37}$ Executive Director of the Open Society Initiative for West Africa, explains how some have gone so far as "to accuse the Court of being a neo-colonialist institution peddling a Western agenda that seeks to control African politics through ICC investigations and prosecutions." For example, Courtenay Griffiths, the lead defense attorney for former Liberian President Charles Taylor, argued that rather than operating through a desire for international justice, the ICC is acts as "a vehicle for its primarily European funders, of which the UK is one of the largest, to exert their power and influence, particularly in Africa." ${ }^{\prime 38}$

Less critical, but still unfavorable interpretations of the ICCs role in Africa assert that the "Achilles heel of the ICC system revolves around the fairness of its selection process of its

\footnotetext{
${ }^{35}$ Franziska Boehme, "“We Chose Africa': South Africa and the Regional Politics of Cooperation with the International Criminal Court," International Journal of Transitional Justice 11, no. 1 (2017), 56.

${ }^{36}$ Bassiouni and Hansen, Inevitable, 309.

${ }^{37}$ Tejan-Cole, ICC, 365.

${ }^{38}$ Courtenay Griffiths, "The International Criminal Court is Hurting Africa," The Telegraph, July 03, 2012.
} 
cases." ${ }^{39}$ Such arguments claim that the ICC suffers from selectivism when deciding which cases to investigate and prosecute. There may be many reasons for this, but Imoedemhe ${ }^{40}$ argues that geopolitical pressures mean that "international crimes are ignored when it is considered politically expedient to do so," and African cases are less likely to have the geopolitical influence to assert pressure to this extent.

Counter arguments to the claims of neo-colonialism and selectivism focus on the application of Complementarity in the Rome Statue, the principle that stipulates that that it is first and foremost "the duty of every State to exercise its criminal jurisdiction over those responsible for international crimes." ${ }^{41}$ Under the complementarity argument, the clustering of cases in Africa is not seen as delierate, but a consequence of histrorical events such as colonialism, war, and "impunity that thrives in a lack of accountability and the rule of law." ${ }^{42}$ Under the complementarity principle, the argument is that clustering of cases in Africa is not deliberate, but a consequence of a historical events such as colonialism, wars, and "impunity that thrives in a lack of accountability and the rule of law." ${ }^{43}$ For those that take this position, such as deGuzman, the ICC is simply doing its job, and "all of the Court's actions to date have been based on plausible interpretations of the relevant law." 44

One of the most persistent critics of the ICC is the African Union, and an example of this is the dispute over arrest warrants issued for heads of state of African Union Countries, particulary Sudanese present Omar Al Bashir. At its July 2010 summit, the African union responded to a second arrest warrant for Omar Al Bashir for Genocide, War Crimes, and Crimes against Humanity by requesting that its member states did not cooperate with the ICC." ${ }^{45}$ This position was reinforced at an Extraordinary Session in Addis Ababa, Ethiopia, in October 2013, where the African Union stated its "concern on the politicization and misuse of indictments against African leaders" reaffirming its position that "no charges shall be commenced or continued before any International Court or Tribunal against any serving AU Head of State or Government." 46 In 2015, the African Union's Committee of African Ministers on International Criminal Court again reiterated their commitment to terminate, suspend, or defer the proceedings against President Al Bashir of Sudan and Deputy President William Samoei Ruto of Kenya until the "concerns and proposals for amendments of the Rome Statute of the ICC are considered. ${ }^{47}$ Since the initial arrest warrant in 2009, Al Bashir has visited eight African states that are signatories to the Rome Statute of the ICC without arrest: Chad, Kenya, Djibouti, Malawi, Nigeria, DRC, South Africa and Uganda. Boehme ${ }^{48}$ suggests this has effectively created a "non-cooperation norm" for exercising ICC warrants in Africa.

As well as the collective opposition from the African Union, individual African states have expressed concerns with the workings of ICC. On October 12, 2016, the Parliament of the Republic

\footnotetext{
${ }^{39}$ Geert-Jan Knoops, An Introduction to the Law of International Criminal Tribunals: A Comparative Study, 2nd ed. (Boston: Brill Nijhoff, 2014), 325.

${ }^{40}$ Ovo Imoedemhe, "Unpacking the Tension between the African Union and the International Criminal Court: The Way Forward," African Journal of International and Comparative Law 23, no. 1 (2015), 80.

${ }^{41}$ United Nations, Rome Statute, 1.

${ }^{42}$ Ibid., 12.

${ }^{43}$ Tamfuh Wilson, "The International Criminal Court: Creation, Competence, and Impact in Africa," African Journal of Criminology \& Justice Studies 3, no. 2 (2008), 114.

${ }^{44}$ Margaret deGuzman, "Is the ICC Targeting Africa Inappropriately? A Moral, Legal, and Sociological Assessment," in Contemporary Issues Facing the International Criminal Court, ed. Richard H. Steinberg (Leiden: Brill, 2016), 333-337.

${ }^{45}$ International Criminal Court, The Prosecutor v. Omar Hassan Ahmad Al Bashir, ICC-02/05-01/09, accessed October 6, 2018, https://www.icc-cpi.int/darfur/albashir.

${ }^{46}$ African Union, Extraordinary Session of the Assembly of the African Union, October 12, 2013, (Ext/Assembly/AU/Dec.12(Oct.2013) and Ext/Assembly/AU/Decl.1-4(Oct.2013)), accessed October 6, 2018, http://www.iccnow.org/documents/ Ext Assembly AU Dec Decl 12Oct2013.pdf.

${ }^{47}$ African Union, "Meeting of the open-ended Committee of African Ministers on International Criminal Court (ICC)," (media advisory, New York, September 26, 2015), accessed October 6, 2018, https://www.au.int/web/en/ newsevents/13173/meeting-open-ended-committee-african-ministers-international-criminal-court-icc-new.

${ }^{48}$ Boehme, Africa, 69.
} 
of Burundi voted in favor of withdrawing from the Rome Statute of the ICC. ${ }^{49}$ They are not the only nation to have done so: South Africa, Kenya, and Gambia have all at some point indicated a desire to withdraw from the statue. On October 27, 2017, Burundi became the first signatory to the Rome Statue to leave the ICC..$^{50}$

Despite the disagreements between the African Union, individual states, and the ICC, there is still much support for the work of the court. For instance, Keppler ${ }^{51}$ claims that the African Union "does not reflect the range of positions that African governments have regarding the ICC." This is supported by Boehme, ${ }^{52}$ who illustrates how the actions of the African Union created a loyalty conflict in South Africa, where the executive is torn between "its obligation to the African Union and its obligation to the ICC." The South African government has been involved for several years in a series of legal challenged around its withdrawal from the ICC, which was eventually found by the high court to be "unconstitutional and invalid." ${ }^{53}$ Furthermore, after South Africa's 2016 proposed withdrawal from the ICC, Nigeria, DRC, Ivory Coast, Botswana, Tunisia, Ghana, Mali, Burkina Faso, Tanzania, Lesotho, and Uganda all publicly backed the Court and its work in Africa.

Although the ICC faces a difficult role in Africa, there are many who believe "the relationship is still salvageable and could be enhanced for the mutual benefit of both institutions with a view to achieving the goal of peace and security. ${ }^{\prime 54}$ Despite an overbalance in ICC cases in Africa, Bassiouni and Hansen argues that this does not mean the ICC should cease investigations here, but that "it needs also to investigate and prosecute crimes elsewhere." ${ }^{55}$ As table 4 shows, there is evidence that the ICC is increasingly focusing its work outside of the African context, with 6 of the 10 preliminary cases in other continents. The only current ICC case pursuant to genocide, however, is in Africa.

\section{Summary}

Since Lemkin's inception of the crime, definitions for genocide have changed little. The subsequent use of Lemkin's crime in legation was, in the words of the Rome Statute, an international response to the idea that there are some crimes so significant that they "shock the conscience of humanity." 56 Nevertheless, the legislation is relatively new and the international responses to genocide newer still. Although the ICC has yet to convict anyone for genocide, previous convictions in international, regional, and local courts, show that there is a desire to pursue those responsible or complicit in this most serious of crimes. Furthermore, bodies such as the ICTR, ICTY, and the ICC have a value that can be judged alongside the number of convictions for genocide and other serious crimes. Hyeran and Simmons argue that the work of the ICC is more nuanced than its record of prosecutions, identifying "multiple mechanisms - legal and social, international and domestic-associated with the ICC's authority that can potentially deter law violation in countries prone to civil violence." 57 They identify two forms of mutually reinforcing deterrent: ${ }^{58}$ firstly, a prosecution deterrent that derives from both the ICCs investigatory powers and from the integration into national laws of the definitions on genocide and associated crimes used by the international courts; and secondly, a social deterrent that derives from the ICCs representation of a mobilization in the international

\footnotetext{
${ }^{49}$ International Criminal Court, "Statement of the President of the Assembly of States Parties on the process of withdrawal from the Rome Statute by Burundi," (statement, October 18, 2016), accessed October 6, 2018, https://www.icc-cpi.int/ Pages/item.aspx?name=pr1244.

${ }^{50}$ European Union, "Statement by the Spokesperson on Burundi and the International Criminal Court," (statement, Brussels, October 27, 2017), accessed October 6, 2018, https://eeas.europa.eu/headquarters/headquartershomepage/34697/statement-spokesperson-burundi-and-international-criminal-court en.

${ }^{51}$ Elise Keppler, “Managing Setbacks for the International Criminal Court in Africa," Journal of African Law 56, no. 1 (2012), $1-14$.

${ }^{52}$ Boehme, Africa, 52.

${ }^{53}$ BBC, "South Africa's Decision to Leave ICC Ruled 'Invalid'," BBC World News, February 22, 2017, accessed October 6, 2018, https://www.bbc.co.uk/news/world-africa-39050408.

${ }^{54}$ Imoedemhe, Unpacking, 74.

55 Bassiouni and Hansen, Inevitable, 324.

${ }^{56}$ United Nations, Rome Statute, 1.

${ }^{57}$ Hyeran and Simmons, International, 444.

${ }^{58}$ Ibid., 468 .
} 
community and in domestic civil society. This is supported by Bassiouni and Hansen, ${ }^{59}$ who describe the ICC as "an institution with the capacity to change habits and outcomes" and by Hillebrecht ${ }^{60}$ who argues that the "ICC's involvement in conflict does have a dampening effect on the level of mass atrocities committed." Nevertheless, the presence of the ICC has not stopped what Lemkin described over 70 years ago as "an old practice in its modern development."

Bibliography

African Union. Extraordinary Session of the Assembly of the African Union, October 12, 2013. Ext/ Assembly/AU/Dec.1-2(Oct.2013) \& Ext/Assembly/AU/Decl.1-4(Oct.2013). Accessed October 6, 2018. http://www.iccnow.org/documents/Ext Assembly AU Dec Decl 12Oct2013.pdf.

."Meeting of the Open-ended Committee of African Ministers on International Criminal Court (ICC)." Media Advisory, September 26, 2016. Accessed October 6, 2018. https://www. au.int/web/en/newsevents/13173/meeting-open-ended-committee-african-ministersinternational-criminal-court-icc-new.

Artucio, Alehandro. The Trial of Macias in Equatorial Guinea: The Story of a Dictatorship. Geneva: International Commission of Jurists, 1979.

Barria, Lilian and Steven Roper. "How Effective are International Criminal Tribunals? An Analysis of the ICTY and the ICTR." International Journal of Human Rights 9, no. 3 (2005), 349-368. https://doi.org/10.1080/13642980500170782

Bassiouni, M. Cherif and Douglass Hansen. "The Inevitable Practice of the Office of the Prosecutor." In Contemporary Issues Facing the International Criminal Court, edited by Richard H. Steinberg, 309-325. Leiden: Brill, 2016. https://doi.org/10.1163/9789004304451 038

BBC. "South Africa's Decision to Leave ICC Ruled 'Invalid'." BBC World News. February 22, 2017. Accessed October 6, 2018. https://www.bbc.co.uk/news/world-africa-39050408.

Boehme, Franziska. "'We Chose Africa': South Africa and the Regional Politics of Cooperation with the International Criminal Court." International Journal of Transitional Justice 11, no. 1 (2017), 50-70.

deGuzman, Margaret. “Is the ICC Targeting Africa Inappropriately? A Moral, Legal, and Sociological Assessment." In Contemporary Issues Facing the International Criminal Court, edited by Richard H. Steinberg, 333-337. Leiden: Brill, 2016. https://doi.org/10.1163/9789004304451 040

European Union. "Statement by the Spokesperson on Burundi and the International Criminal Court." Statement, Brussels, October 27, 2017. Accessed October 6, 2018. https://eeas.europa. eu/headquarters/headquarters-homepage/34697/statement-spokesperson-burundi-andinternational-criminal-court en.

Griffiths, Courtenay. "The International Criminal Court is Hurting Africa." The Telegraph, July 3, 2012. Accessed October 6, 2018. http://www.telegraph.co.uk/news/worldnews/ africaandindianocean/kenya/9373188/The-International-Criminal-Court-is-hurtingAfrica.html.

Hillebrecht, Courtney. "The Deterrent Effects of the International Criminal Court: Evidence from Libya." International Interactions 42, no. 4 (2016), 616-643. https://doi.org/10.1080/03050629.2016.1185713

Hobson, Jonathan. "Three Theoretical Approaches to Lemkin's Definition of Genocide." Genocide Studies and Prevention 13, no. 1 (2019), 11-18.

Hyeran, Jo and Beth Simmons. "Can the International Criminal Court Deter Atrocity?" International Organization 70, no. 3 (2016), 443-475. https://doi.org/10.1017/S0020818316000114

International Criminal Court. "Understanding the International Criminal Court." Public Information and Documentation Section. Accessed October 6, 2018. https://www.icc-cpi. int/iccdocs/pids/publications/uicceng.pdf.

---------. "Statement of the President of the Assembly of States Parties on the process of withdrawal

${ }^{59}$ Bassiouni and Hansen, Inevitable, 311.

${ }^{60}$ Hillebrecht, Deterrent, 616.

${ }^{61}$ Lemkin, Axis, 79. 
from the Rome Statute by Burundi." Statement, October 18, 2016. Accessed October 6, 2018. https://www.icc-cpi.int/Pages/item.aspx?name=pr1244.

. "Current Judges." Judicial Divisions. Accessed October 6, 2018. https://www.icc-cpi.int/ about/judicial-divisions/biographies.

Imoedemhe, Ovo. "Unpacking the Tension between the African Union and the International Criminal Court: The Way Forward." African Journal of International and Comparative Law 23, no. 1 (2015), 74-105. https://doi.org/10.3366/ajicl.2015.0111

Keppler, Elise. "Managing Setbacks for the International Criminal Court in Africa." Journal of African Law 56, no. 1 (2012), 1-14. https://doi.org/10.1017/S0021855311000209

Knoops, Geert-Jan. An Introduction to the Law of International Criminal Tribunals: A Comparative Study, 2nd ed. Boston: Brill Nijhoff, 2014.

Lemkin, Raphaël. Axis Rule in Occupied Europe: Laws of Occupation, Analysis of Government, Proposal for Redress. Washington, DC: Carnegie Endowment for International Peace, 1944.

Nwoye, Leo, C. "Partners or Rivals in Reconciliation? The ICTR and Rwanda's Gacaca Courts." San Diego International Law Journal 16, no. 1 (2014), 119-208.

Republic of Rwanda. Organic Law No. 40/2000. January 26, 2001. Accessed October 6, 2018. http:// jurisafrica.org/docs/statutes/ORGANIC\%20LAW\%20N0\%2040.pdf.

Schabas, William. Convention for the Prevention and Punishment of the Crime of Genocide. United Nations Audiovisual Library of International Law, 2008. Accessed June 10, 2018. http:// legal.un.org/avl/pdf/ha/cppcg/cppcg e.pdf.

Tejan-Cole, Abdul. "Is the ICC's Exclusively African Case Docket a Legitimate and Appropriate Intervention or an Unfair Targeting of Africans?" In Contemporary Issues Facing the International Criminal Court, edited by Richard H. Steinberg, 366-379. Leiden: Brill, 2016. https://doi.org/10.1163/9789004304451043

United Nations. Rome Statute of the International Criminal Court. July 17, 1998 and corrected by process-verbaux of November 10, 1998, July 12, 1999, November 30, 1999, May 8, 2000, January 17, 2001 and January 16, 2002. UN Doc. A/CONF.183/9.

------. Yearbook of the International Law Commission 1950, Vol. 2. New York: United Nations Publication, 1957.

--------. The Charter and Judgment of the Nürnberg Tribunal - History and Analysis, Memorandum submitted by the Secretary-General, Formulation of the Nürnberg Principles. 1949. UN Doc. A/ CN.4/5.

--------. The Yearbook of the United Nations 1946-17. New York: United Nations Publications, 1947. -. Updated Statute of the International Criminal Tribunal for the Former Yugoslavia. September 2009. Compilation based on original United Nations resolutions. Accessed October 6, 2018. http://www.icty.org/x/file/Legal Library/Statute/statute sept09 en.pdf.

Wilson, Tamfuh. "The International Criminal Court: Creation, Competence, and Impact in Africa." African Journal of Criminology \& Justice Studies 3, no. 2 (July 2008), 85-123. 